\title{
Angiotensin converting enzymes ACE and ACE2 in thyroid cancer progression
}

\author{
S. S. NARAYAN ${ }^{1}$, K. LORENZ1 ${ }^{1}$ J. UKKAT ${ }^{1}$, C. HOANG-VU1', B. TROJANOWICZ ${ }^{2, *}$ \\ ${ }^{1}$ Department of Visceral, Vascular and Endocrine Surgery, Martin Luther University Halle-Wittenberg, Germany; ${ }^{2}$ Department of Internal \\ Medicine II, Martin Luther University Halle-Wittenberg, Germany
}

${ }^{*}$ Correspondence: bogusz.trojanowicz@uk-halle.de

Received May 6, 2019 / Accepted July 11, 2019

\begin{abstract}
Angiotensin-converting enzymes, ACE and ACE2, play not only a pivotal role in the regulation of blood pressure, but are involved in the processes of pathophysiology, including thyroid dysfunction or progression of several neoplasia such as cancers of skin, lungs, pancreas and leukemia. However, their role in the thyroid carcinogenesis remains unknown. We examined in this study the expression of ACE and ACE2 in thyroid tissues and their possible employment as biomarkers for thyroid cancer progression. Thyroid tissues, including 14 goiters (G), 12 follicular adenomas (FA), 10 follicular thyroid carcinomas (FTC), 14 papillary thyroid carcinomas (PTC) and 11 undifferentiated thyroid carcinomas (UTC), were subjected to RT-PCR and protein analyses with primers or antibodies specific for ACE and ACE2, respectively. FA revealed significantly increased ACE compared to other groups and FTC was significantly higher than UTC. ACE2 was significantly increased in PTC in comparison to G, FA and UTC, and in FTC as compared to G. The ratio ACE/ACE2 decreased, while ACE2/ACE increased with the differentiation grade of thyroid carcinoma. ACE was significantly diminished in individuals older than 50. Both ACEs were significantly diminished in M1 patients, ACE2 additionally in higher tumor masses. ACE and ACE2 are regulated within thyroid benign and malignant tissues. As the transcript ratio between both enzymes correlate proportional with the differentiation status of thyroid cancer, ACE and ACE2 may serve as new markers for thyroid carcinoma.
\end{abstract}

Key words: ACE, ACE2, thyroid cancer, follicular adenoma, renin, angiotensin

Thyroid carcinoma belongs to the most frequently observed endocrine malignancies and together with non-malignant, thyroid hormone (TH)-mediated disorders may affect the other systems, including renin angiotensin system (RAS). The components of RAS may act on individual organs systematically or locally and it is well known that abnormal levels of $\mathrm{TH}$ may affect their proper functioning [1-3]. The actions of the classical RAS are mediated by ACE, which generates Angiotensin II (AngII), a potent vasoconstrictor and main RAS effector. The pro-inflammatory and pro-proliferative actions of AngII may be counteracted by the recently described ACE2, which degrades AngII to Angiotensin 1-7 (Ang 1-7), a potent vasodilator possessing also anti-proliferative properties [4, 5]. Both ACEs, abundantly expressed in human cardiac, pulmonary and renal tissues [6-8], have also been detected on monocytes [9-11] and in human atherosclerotic lesions, where they were associated with a subset of lesion macrophages [12-15]. Furthermore, ACE and ACE2 may act as important components of tumor microenvironment and by interaction with different adhesion-related factors, such as
E-cadherin [16] or cytokines, such as TGFb [17], are able to modulate the epithelial-to-mesenchymal transformation [18], crucial for processes of neoplasia [19].

Hypo- or hyperthyroidism which is potentially related to the insufficient or excess production of $\mathrm{TH}$, respectively, may affect the levels of ACEs, AngII and Ang 1-7. It has been demonstrated that over-activation of thyroid gland is associated with increased ACE or AngII in plasma [20], heart [21, 22] and kidney [23], whereas hypothyroid state exerted contrary effects $[24,22]$. With regards to the ACE2, recent data revealed that hyperthyroidism-induced cardiac hypertrophy was accompanied with cardiac activation of ACE2 and Ang 1-7 [25]. In patients with renal failure who frequently tend to present hypothyroidism and enlargement of the thyroid gland $[26,27]$, the levels of ACE on monocytes are increased, whereas ACE2 is noticeably decreased [28, 29]. Additionally, these patients obviously suffer from chronic inflammation related with increased levels of TNF and IL-1. As these two cytokines inhibit the proper conversion of $\mathrm{TH}$ in the target tissues, it seems explainable how uremia may impair the proper functioning of the thyroid gland [30-32]. 
Since there is a clear correlation between TH, RAS and different pathological conditions, and the increased number of tumor-associated monocyte-derived macrophages infiltrating thyroid carcinoma tissues could be detected [33-35], we investigated in this study the expression of both ACEs in thyroid gland and their possible employment as diagnostic markers for thyroid carcinoma.

\section{Patients and methods}

Patients and tissue preparation. A total of 61 thyroid tissues, including 14 goiter tissues (G), 12 follicular adenoma (FA), 10 follicular thyroid carcinomas (FTC), 14 papillary thyroid carcinomas (PTC) and 11 undifferentiated thyroid carcinomas (UTC), were collected from patients treated in the time interval from 1994 to 2011 at the Department of Surgery of the Martin-Luther-University Halle, by surgical resection. Pathological diagnosis of tissue sections was confirmed with hematoxylin and eosin staining (Table S1). All tissues were snap frozen in liquid nitrogen and stored at $-80^{\circ} \mathrm{C}$ for further proceedings. Out of 61 patients $21.3 \%$ suffered from cardiovascular disorders (CVD), 16.4\% were taking calcium channel blockers $(\mathrm{CBB})$ and $9.8 \%$ angiotensin II modifying medication (ACEi/ARB, Table S1). Total RNA was extracted from all samples by employment of Trizol reagent according to the manufacturer's instructions (Gibco).

Total RNA obtained from SW-480 cells representing colorectal adenocarcinoma, served as positive control, and was prepared and handled the same way as tissue extracts. Additionally, selected tissues from all groups were investigated in immunohistochemical studies with antibodies specific for ACE and ACE2, as described below. This study was approved by the ethics committee of the Martin Luther University, Faculty of Medicine, and all patients gave written consent.

RT-PCR. One $\mu \mathrm{g}$ of total RNA was reversely transcribed with Superscript II kit (Gibco, Munich, Germany) at $42^{\circ} \mathrm{C}$ for $30 \mathrm{~min}$ followed by enzyme inactivation at $95^{\circ} \mathrm{C}$ for $5 \mathrm{~min}$.

Amplifications of target and housekeeping gene transcripts were performed with primer pairs mentioned in Table S2 and Rotor-Gene SYBR Green PCR Master Mix (Qiagen, Hilden, Germany). Thermal cycling conditions were as follows: hold $5 \mathrm{~min}$ at $95^{\circ} \mathrm{C}$, followed by 40 cycles of $5 \mathrm{~s}$ at $95^{\circ} \mathrm{C}$ and $10 \mathrm{~s}$ at $60^{\circ} \mathrm{C}$. Data evaluation was performed with Rotor-Gene $\mathrm{Q}^{\mathrm{Tm}}$ real-time PCR software. Dotted line within the qPCR graphs represents the expression of the target transcript in the reference sample (SW-480) and for the evaluation purposes was set as $100 \%$. For the whole study, and for all qPCR reactions, the same internal calibrator, the same negative controls and the same normalizing marker were employed.

Immunohistochemistry. Freshly cut cryo-embedded serial $6 \mu \mathrm{m}$ sections of selected thyroid tissues were washed with PBS and fixed in a 1:4 mixture of $3 \% \mathrm{H}_{2} \mathrm{O}_{2}$ in ice cold $90 \%$ methanol for $20 \mathrm{~min}$. After washing twice with PBS, cells were incubated overnight at $4^{\circ} \mathrm{C}$ with the rabbit polyclonal antibodies against ACE and ACE2 (ab85955 or ab15348, respectively, both diluted 1:1000 with PBS; both from Abcam, Cambridge, MA, USA). Negative control sections were exposed to the secondary antibody only and processed as described below. After $3 \times 10$ min washing in PBS, cells were incubated for $30 \mathrm{~min}$ with a 1:1000 dilution of biotinylated goat anti-rabbit secondary antibody followed by incubation with an avidin-biotin-peroxidase complex. After $3 \times 10 \mathrm{~min}$ washing in PBS, specific immunostaining was visualized with diaminobenzidine chromogenic solution (1:50). Finally, cells were lightly counterstained with Mayer's hematoxylin and photographed under light microscope (Biozero BZ-9000, Keyence Deutschland GmbH, Germany).

Western blot. Total protein extraction from liquidnitrogen homogenized tissues was performed with a protein lysis buffer (7M urea, $2 \mathrm{M}$ thiourea, 4\% CHAPS, $40 \mathrm{mM}$ DTT) supplemented with protease inhibitors. Forty $\mu \mathrm{g}$ of total protein was separated on $12 \%$ SDS-PAGE and blotted onto PVDF membranes. Membranes were blocked $1 \mathrm{~h}$ in $5 \%$ non-fat milk dissolved in TBST buffer. Thereafter primary ACE, ACE2 (both 1:1000, Abcam, ab85955 and ab15348, respectively) and $\beta$-actin (1:10000, Sigma Aldrich, A5441, clone AC-15) antibodies in blocking buffer were applied overnight at $4{ }^{\circ} \mathrm{C}$ and for $1 \mathrm{~h}$ at room temperature respectively. Finally, secondary anti-rabbit and anti-mouse- HRP-conjugated antibodies (both 1:10000, SCBT, sc-2004 and sc-2005, respectively) were employed ( $1 \mathrm{~h}$ at room temperature). Protein bands were visualized with ECL kit (Advansta, WesternBright ECL HRP substrate) and ChemiDoc ${ }^{\mathrm{Tm}} \mathrm{MP}$ Imaging System (Bio-Rad).

Statistics. Each experiment was performed in quadruplicates. Distribution of the quantitative variables was tested with D’Agostino \& Pearson, Shapiro-Wilk or KolmogorowSmirnow normality tests. Depending on data distribution, parametric (differences between paired values are consistent) or non-parametric (Wilcoxon matched-pairs signed rank test) two-sided t tests were used. Data are presented as medians with inter quartile ranges. For comparisons within thyroid tissues, Bonferroni correction was applied and p-values ${ }^{*}<0.01,{ }^{* *}<0.001$ and ${ }^{* * *}<0.0001$ indicated statistical significance. All analyses were performed with GraphPad Prism 6 software.

\section{Results}

Expression of ACE and ACE2 on total tissue extracts. Total RNA obtained from patients' tissues with known diagnosis was subjected to RT-PCR with primers specific for ACE and ACE2. The expression of ACE transcripts was detected noticeably stronger in FA as compared with $G$ and carcinoma tissues. ACE expression was significantly stronger in FA as compared to FTC and significantly lower in UTC as compared to FTC (Figure 1A). Increased expression of ACE2 was observed in PTC and FTC as compared to the other tissues investigated. Significantly increased levels of ACE2 
A
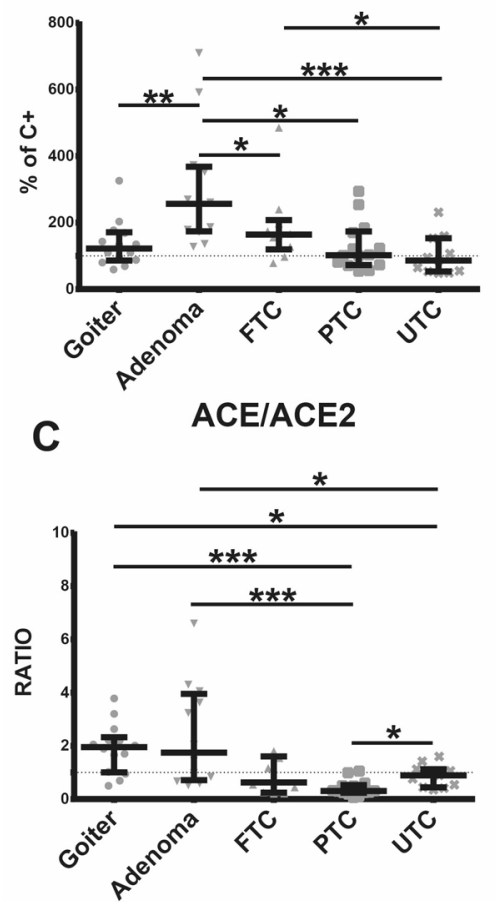

E

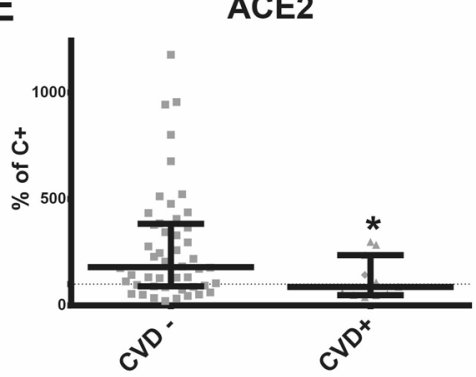

B

ACE2
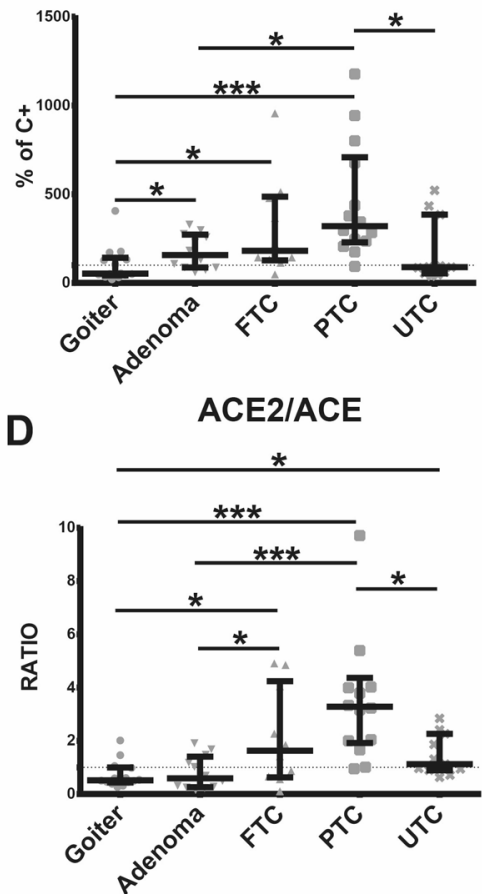

F

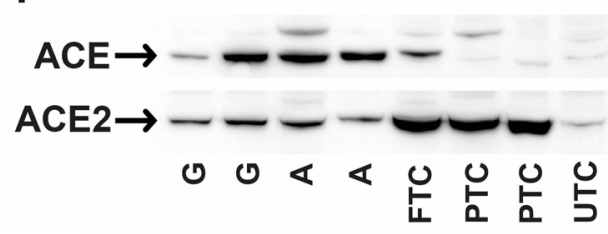

$\beta$-Actin $\rightarrow$

Figure 1. Quantitative RT-PCR analysis performed on human thyroid samples. Total RNA obtained from goiter (G), follicular adenoma (Adenoma, A), follicular thyroid carcinoma (FTC), papillary thyroid carcinoma (PTC) and undifferentiated thyroid carcinoma (UTC) were reversely transcribed and amplified with the primers specific for ACE and ACE2. Expression of ACE (A) and ACE2 (B) in thyroid samples was compared to the expression of both transcripts in SW-480 cells (positive control defined as $100 \%$ and $\mathrm{C}+$ ) and evaluated as percentage difference (\% of $\mathrm{C}+$ ); dotted line in $\mathrm{A}$ and $\mathrm{B}$ represents the expression of the target transcripts (ACE and ACE2) in positive control. Expression ratio between (C) ACE and ACE2, and (D) ACE2 and ACE. ACE or ACE2 expression in each individual sample was divided by ACE2 or ACE expression in this same sample, respectively; dotted line in $\mathrm{C}$ and $\mathrm{D}$ represents the ratio between target transcripts in the reference sample and for evaluation purposes was set as 1 . (E) Expression of $\mathrm{ACE} 2$ in patients with (CVD+) or without (CVD-) cardiovascular disorders. (F) Representative western blots demonstrating protein expression of ACE and ACE2 in thyroid tissues; note that $\beta$-actin served as loading control marker; medians with IRQs; p-values ${ }^{*}<0.01,{ }^{* *}<0.001$ and ${ }^{\star * *}<0.0001$ indicate statistical significance (Bonferroni correction was applied).

were detected in PTC as compared to G or FA (Figure 1B). Expressions of ACE and ACE2 in UTC were relatively weak in comparison with differentiated thyroid carcinoma (Figure 1). The median percentage transcript expression for ACE in each histological subgroup was $122.0 \%$ (59.0-326.0, G), 256.50\% (128.0-710.0, FA), 164.0\% (78.0-485.0, FTC), $102.0 \%$ (54.0-294.0, PTC) and 86.0\% (48.0-231.0, UTC). Analysis of ACE2 revealed following median percentages: 52.5\% (21.0-406.0, G), 157.0\% (61.0-329.0, FA), $181.0 \%$
(47.0-955.0, FTC), 320.0\% (93.0-1177.0, PTC) and $89.0 \%$ (39.0-522.0, UTC).

Furthermore, investigations of the expression proportion between both transcripts revealed that ratio ACE/ACE2 decreased, while ACE2/ACE increased with the differentiation grade of thyroid carcinoma (Figures 1C, D). We found no correlations between ACEs expression and CBB or AngII modifying medication. ACE2 was significantly diminished in patients with CVD (Figure 1E). 


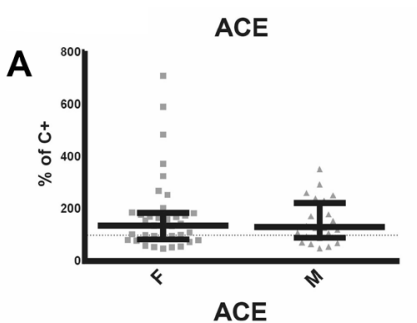

B
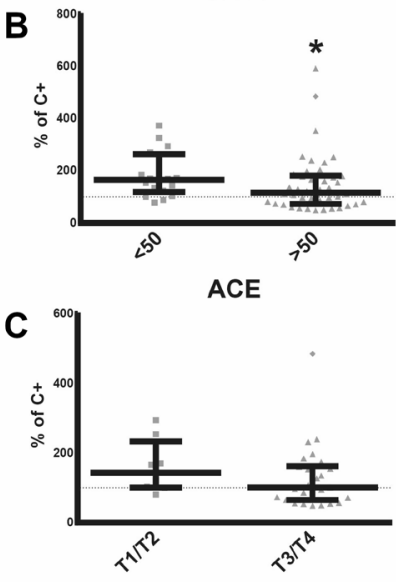

ACE
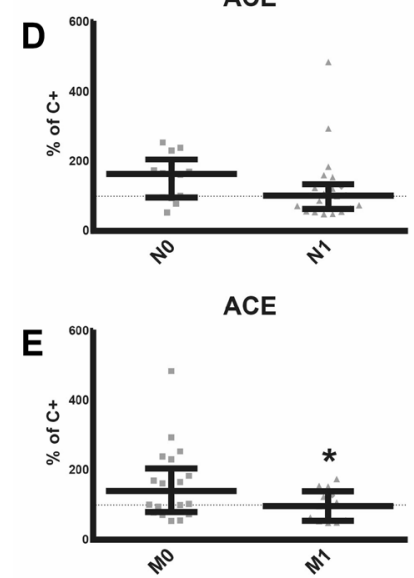

Figure 2. Evaluation of ACE and ACE2 expression regarding gender (A), age (B), tumor grade (C), lymph node (D) and metastatic status (E); dotted line represents the expression of the target transcripts (ACE and ACE2) in positive control and for evaluation purposes was set as $100 \%$; medians with IRQs; p-values ${ }^{*}<0.05$ were considered to indicate statistical significance.

Correlation with age, gender, tumor grade, lymph node and metastatic status. We found no difference in ACE and ACE2 expression between females and males. However, ACE2 expression in male group revealed a falling tendency (Figure 2A). The transcripts of both enzymes demonstrated decreased expression in the group of patients older than 50 years (Figure 2B), as well as in individuals with diagnosed T3/T4 tumors (Figure 2C), lymph node (Figure 2D) and distant metastases (Figure 2E) as compared to corresponding controls. It is worth to note that expression of ACE was significantly decreased in patients older than 50 (Figure 2B) and with M1 status (Figure 2E). ACE2 was significantly diminished in patients with higher tumor masses (Figure 2C) and distant metastases (Figure 2E). The median percentage transcript expression for ACE in each group investigated was $136.0 \%(48.0-710.0, \mathrm{~F})$ vs. $131.0 \%(49.0-353.0, \mathrm{M})$; $165.5 \%(78.0-373.0,<50$ years $)$ vs. $115.5 \%(48.0-592.0,>50$ years); $143.5 \%$ (81.0-294.0, T1/T2) vs. $104.0 \%$ (48.0-485.0, T3/T4); $164.0 \%$ (53.0-254.0, N0) vs. $101.5 \%$ (48.0-485.0, N1); $140.5 \%$ (54.0-485.0, M0) vs. 97.0\% (48.0-174.0, M1). Analysis of ACE2 revealed following median percentages: $175.0 \%$ (21.0-943.0, F) vs. $129.5 \%$ (32.0-1177.0, M); $211.5 \%$ (45.0-677.0, <50 years) vs. $113.0 \%(21.0-1177.0,>50$ years); $407.5 \%$ (143.0-1177, T1/T2) vs. $159.0 \%$ (39.0-955.0, T3/T4); $365.0 \%(60.0-955.0, \mathrm{~N} 0)$ vs. $241.0 \%(39.0-1177.0, \mathrm{~N} 1)$; $354.5 \%$ (39.0-1177.0, M0) vs. 96.0\% (46.0-512.0, M1).

Protein expression of ACE and ACE2 on thyroid tissues. To investigate the cellular localization and expression of both proteins within benign and malignant thyroid tissues, selected surgical resectates were subjected to immunohistochemistry and western blot with specific ACE and ACE2 antibodies. Both proteins were mostly localized in the cytoplasm of the thyroid cells, although sporadic positive ACE and ACE2 staining could be detected in nucleus. Weaker ACE immunoreactivity was detected in G and most thyroid carcinoma tissues representing FTC, PTC and UTC as compared with FA (Figure 3A). In contrast, ACE2 was noticeably higher in FTC and PTC as compared with other investigated tissues (Figure 3B). In addition to these findings, ACE2 protein expression in FTC and PTC was noticeably stronger than that of ACE, further supporting the results obtained on transcript level (Figure 1F, Figure 3).

\section{Discussion}

In this study, we identified ACE and ACE2 transcripts as novel RAS indicators of the malignant state of thyroid gland. We found that levels of both transcripts are regulated within benign and malignant tissues, and that expression ratios between ACEs correlate proportional with the differentiation status of thyroid cancer. Furthermore, and the most importantly, based on the expression of ACE or ACE2/ACE ratio we could distinguish between FA and FTC of the thyroid gland. To our knowledge, this is the first study demonstrating that both RAS components, ACE and ACE2 may be involved in the processes of thyroid carcinogenesis and possess the diagnostic properties.

Several studies demonstrated that RAS may be involved in tumor progression and angiogenesis. The results originating from a mouse melanoma model suggest that enhanced AngII signaling supports the infiltration of tumor-associated macrophages, resulting in enhanced tissue VEGF protein levels [36]. Furthermore, administration of AngII-modifying medication, especially employment of ACE-inhibitors 

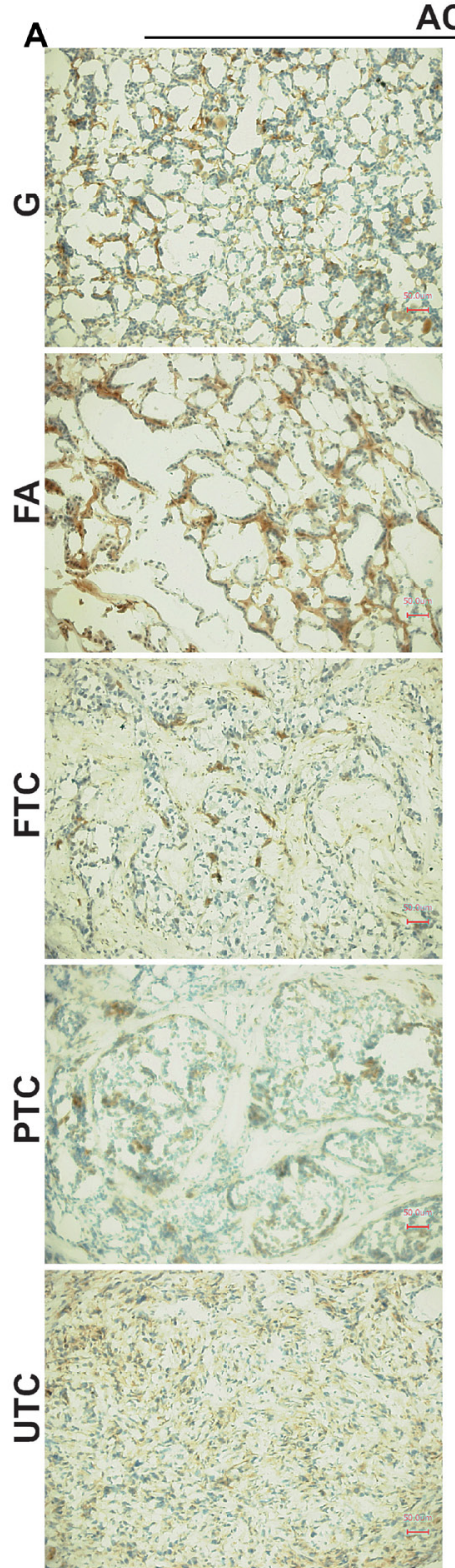

ACE
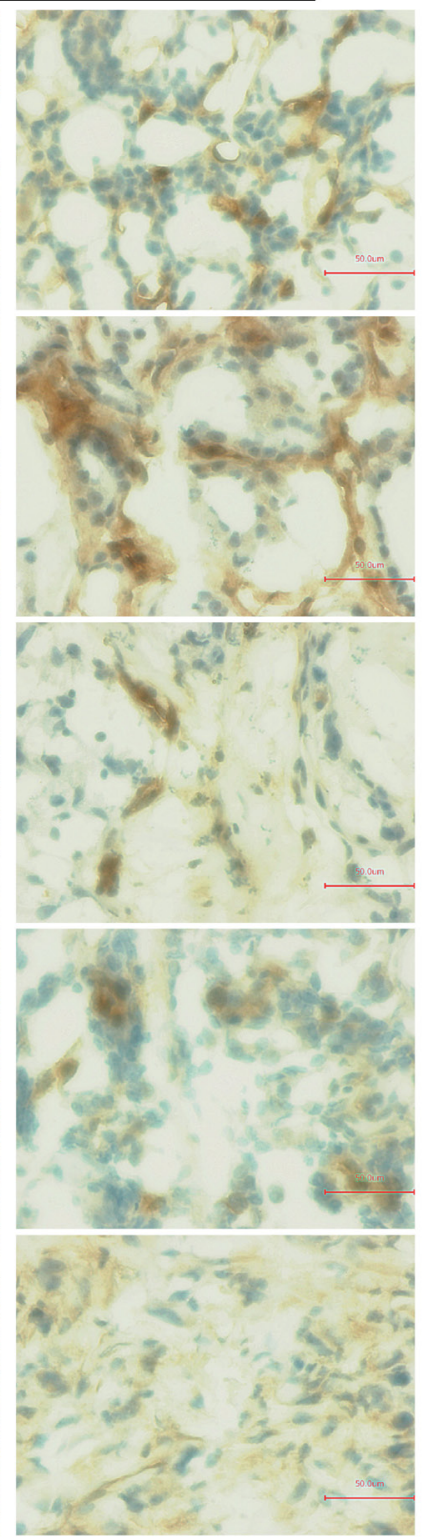

B
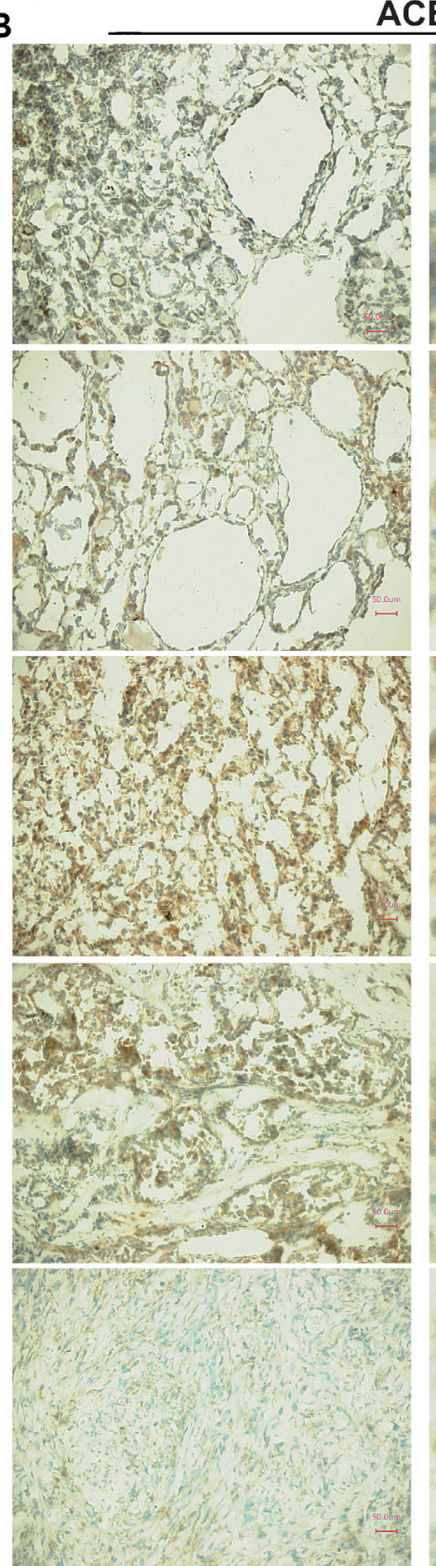

ACE2
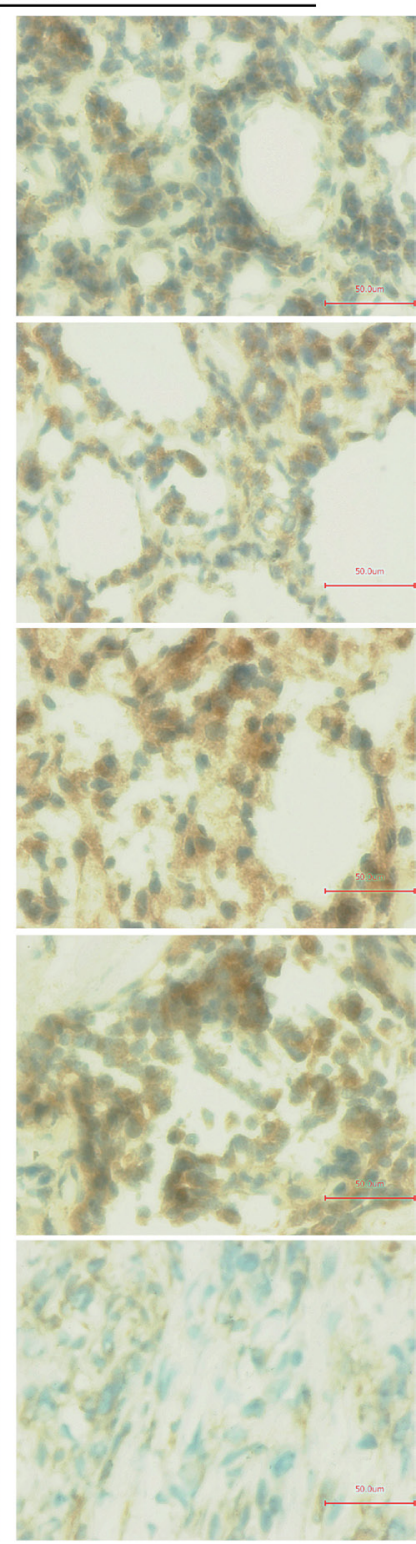

Figure 3. Representative immunohistochemical analysis of ACE (A) and ACE2 (B) expression on thyroid tissues. Frozen, freshly cut serial $6 \mu$ m cryosections were stained with specific ACE or ACE2 antibodies, visualized with diaminobenzidine chromogenic solution and counterstained with Mayer's hematoxylin. Note strong ACE2 staining in papillary thyroid carcinoma (PTC) and follicular thyroid carcinoma (FTC) as compared to ACE immunoreactivity in those tissues; note stronger ACE staining in follicular adenoma (FA) than in other tissues investigated; note strong ACE2 production in FTC and PTC as compared to goiter (G), FA and undifferentiated thyroid carcinoma (UTC).

(ACEi), was linked with anti-cancer effects as reflected in decreased proliferation and invasion of tumor cells, as well as reduced angiogenesis or metastatic potential both in vitro and in vivo [37-39]. On the other hand, in ACE 10/10 mice model the high levels of ACE on macrophages provided a consistent and marked resistance to melanoma proliferation. It is worth to note that in the absence of any tumor environment, these macrophages reacted to LPS stimuli with increased levels of IL-12 and nitrite production, whereas IL-10 production was diminished [40].

Recent population based cohort study by Hicks et al. suggested that the use of ACEi was associated with an increased risk of lung cancer, particularly in individuals taking this medication for more than five years [41]. A metaanalysis study by Song et al. revealed that administration of angiotensin modifying medication exerted beneficial effects 
on urinary tract cancer, colorectal cancer, pancreatic cancer and prostate cancer, but not on the breast and hepatocellular cancer [38]. Various studies reported the regulation of ACE and ACE2 in several cancer types. Increased ACE serum levels, reported in patients with laryngeal cancer, were associated with poor prognosis [42], whereas in patients suffering from primary lung cancer, higher amounts of circulating ACE predicted better clinical outcome [43]. Prochazka et al. demonstrated a decreased ACE activity in primary human lung tumors as compared to corresponding normal lung tissue [44]. Furthermore, in patients with bronchial carcinoma elevated plasma ACE activity reflected the effective response to chemotherapy or radiotherapy $[45,46]$. In patients with acute myeloid leukemia, ACE was noticeably overexpressed in leukemic myeloid blast cells as compared with control group, representing individuals with non-malignant hematological disorders [47]. Also the multiple myeloma patients demonstrated significantly elevated ACE serum levels as compared with control groups [48].

With regards to $\mathrm{ACE} 2$, it has been demonstrated that breast cancer cells overexpressing ACE2, possess decreased metastatic ability in immunodeficient mouse model. The same study reported highly expressed ACE2 in adjacent and ductal cancer tissues, whereas in samples with distant or lymph node metastasis, low levels of ACE2 were observed [49]. In other animal models, injection of Ang 1-7, a product of ACE2 actions, led to decreased growth and metastatic ability of lung and prostate cancers [50-52]. Similar results were also observed for pancreatic cancer, where cellular overexpression of ACE2 led to diminished tumorigenicity and tumor growth, both in vitro and in vivo [53].

We found in our studies significantly low levels of ACE and ACE2 in the most malignant samples representing UTC, whereas in differentiated thyroid carcinoma tissues, such as PTC, ACE expression was low, but ACE2 was noticeably upregulated as compared to non-malignant samples. Furthermore, both enzymes demonstrated a falling tendency in samples originating from higher tumor sizes and metastatic lesions. With regard to ACE2, it worth to note, that its expression reached significantly low levels in bigger tumors and in individuals producing distant metastases.

What is the possible mechanism or role of both enzymes in thyroid cancer progression? It seems that enzymatic activity of at least one of the ACEs may play an important role in tumor growth and metastases. Yu et al. demonstrated that anti-proliferative effects of ACE2 might be abolished upon inhibition of Ang 1-7 receptor and the silencing of ACE2/ Ang-(1-7)/Mas axis was related with increased calcium influx and activation of PAK1/NF- $\kappa \mathrm{B} /$ Snail1 signaling [49]. Based on our data and especially the ratio between both enzymes, we speculate that pro-inflammatory and pro-proliferative actions of AngII generation cannot be effectively counterbalanced by ACE2 activity or Ang 1-7 actions. This fact may be further supported by the observations that although thyroid tumor samples possess relatively high ACE2/ACE ratios, the tissues producing lymph node or distant metastases reveal significantly diminished ACE2 levels that per se may correlate with decreased ACE2 activity.

Although the exact functional or biological rationale of ACE or ACE2 remains not entirely understood for thyroid carcinogenesis, both enzymes proved to have a valuable diagnostic potential. Furthermore, as the expression of ACE allows discriminating between FA and FTC lessons, it would be of great interest to verify whether the circulating blood levels of both enzymes may support the development of serum/plasma non-invasive assay useful for diagnostic of thyroid cancer.

Limitations. Although this study was investigated on human tissues originating from patients with different thyroid disorders we must address several limitations. By design, the expression of both ACEs could be obtained on the transcript and protein levels, however the measurements of enzymatic activity of both enzymes in the circulation or thyroid tissues are missing. The lack of functional data, especially the influence of AngII-modifying medication on thyroid cancer progression, which is a noticeable limitation of this study, should be addressed in the future. We are aware that this study was conducted on relatively small patients' collective, but the promising results presented in this report justify future investigations on larger cohorts.

Supplementary information is available in the online version of the paper.

Acknowledgements: We would like to thank Ms. Kathrin Hammje for excellent technical assistance in creation of this manuscript.

\section{References}

[1] VARGAS F, MORENO JM, RODRÍGUEZ-GÓMEZ I, WANGENSTEEN R, OSUNA A et al. Vascular and renal function in experimental thyroid disorders. Eur J Endocrinol 2006; 154: 197-212. https://doi.org/10.1530/eje.1.02093

[2] KLEIN I, OJAMAA K. Thyroid hormone and the cardiovascular system. N Engl J Med 2001; 344: 501-509. https://doi. org/10.1056/NEJM200102153440707

[3] ICHIKI T. Thyroid hormone and atherosclerosis. Vascul Pharmacol 2010; 52: 151-156. https://doi.org/10.1016/j. vph.2009.09.004

[4] DONOGHUE M, HSIEH F, BARONAS E, GODBOUT K, GOSSELIN $\mathrm{M}$ et al. A novel angiotensin-converting enzyme-related carboxypeptidase (ACE2) converts angiotensin I to angiotensin 1-9. Circ Res 2000; 87: E1-9. https://doi. org/10.1161/01.res.87.5.e1

[5] SANTOS RA, SIMOES E SILVA AC, MARIC C, SILVA DM, MACHADO RP et al. Angiotensin-(1-7) is an endogenous ligand for the $G$ protein-coupled receptor Mas. Proc Natl Acad Sci U S A 2003; 100: 8258-8263. https://doi. org/10.1073/pnas. 1432869100 
[6] YE M, WYSOCKI J, WILLIAM J, SOLER MJ, COKIC I et al. Glomerular localization and expression of Angiotensin-converting enzyme 2 and Angiotensin-converting enzyme: implications for albuminuria in diabetes. J Am Soc Nephrol 2006; 17: 3067-3075. https://doi.org/10.1681/ ASN.2006050423

[7] SOLER MJ, WYSOCKI J, BATLLE D. ACE2 alterations in kidney disease. Nephrol Dial Transplant 2013; 28: $2687-$ 2697. https://doi.org/10.1093/ndt/gft320

[8] IMAI Y, KUBA K, RAO S, HUAN Y, GUO F et al. Angiotensin-converting enzyme 2 protects from severe acute lung failure. Nature 2005; 436: 112-116. https://doi.org/10.1038/ nature 03712

[9] KITAZONO T, PADGETT RC, ARMSTRONG ML, TOMPKINS PK, HEISTAD DD. Evidence that angiotensin II is present in human monocytes. Circulation 1995; 91: 1129-1134. https://doi.org/10.1161/01.cir.91.4.1129

[10] CHEN X, LU H, ZHAO M, TASHIRO K, CASSIS LA et al. Contributions of leukocyte angiotensin-converting enzyme to development of atherosclerosis. Arterioscler Thromb Vasc Biol 2013; 33: 2075-2080. https://doi.org/10.1161/ATVBAHA.113.301777

[11] THATCHER SE, ZHANG X, HOWATT DA, LU H, GURLEY SB et al. Angiotensin-converting enzyme 2 deficiency in whole body or bone marrow-derived cells increases atherosclerosis in low-density lipoprotein receptor-/- mice. Arterioscler Thromb Vasc Biol 2011; 31: 758-765. https:/doi. org/10.1161/ATVBAHA.110.221614

[12] SCHIEFFER B, SCHIEFFER E, HILFIKER-KLEINER D, HILFIKER A, KOVANEN PT et al. Expression of angiotensin II and interleukin 6 in human coronary atherosclerotic plaques: potential implications for inflammation and plaque instability. Circulation 2000; 101: 1372-1378. https://doi. org/10.1161/01.cir.101.12.1372

[13] O'BRIEN KD, SHAVELLE DM, CAULFIELD MT, MCDONALD TO, OLIN-LEWIS $\mathrm{K}$ et al.: Association of angiotensin-converting enzyme with low-density lipoprotein in aortic valvular lesions and in human plasma. Circulation 2002; 106: 2224-2230. https://doi.org/10.1161/01. cir.0000035655.45453.d2

[14] SLUIMER JC, GASC JM, HAMMING I, VAN GOOR H, MICHAUD A et al. Angiotensin-converting enzyme 2 (ACE2) expression and activity in human carotid atherosclerotic lesions. J Pathol 2008; 215: 273-279. https://doi. org/10.1002/path.2357

[15] ZULLI A, BURRELL LM, WIDDOP RE, BLACK MJ, BUXTON BF et al. Immunolocalization of ACE2 and AT2 receptors in rabbit atherosclerotic plaques. J Histochem Cytochem 2006; 54: 147-150. https://doi.org/10.1369/jhc.5C6782.2005

[16] YU C, TANG W, WANG Y, SHEN Q, WANG B et al. Downregulation of ACE2/Ang-(1-7)/Mas axis promotes breast cancer metastasis by enhancing store-operated calcium entry. Cancer Lett 2016; 376: 268-277. https://doi. org/10.1016/j.canlet.2016.04.006

[17] COOK KL, METHENY-BARLOW LJ, TALLANT EA, GALLAGHER PE. Angiotensin-(1-7) reduces fibrosis in orthotopic breast tumors. Cancer Res 2010; 70: 8319-8328. https://doi.org/10.1158/0008-5472.CAN-10-1136
[18] BURNS WC, VELKOSKA E, DEAN R, BURRELL LM, THOMAS MC. Angiotensin II mediates epithelial-tomesenchymal transformation in tubular cells by ANG 1-7/ MAS-1-dependent pathways. Am J Physiol Renal Physiol 2010; 299: F585-593. https://doi.org/10.1152/ajprenal.00538.2009

[19] DE CRAENE B, BERX G. Regulatory networks defining EMT during cancer initiation and progression. Nat Rev Cancer 2013; 13: 97-110. https://doi.org/10.1038/nrc3447

[20] PHILLIPS MI, SPEAKMAN EA, KIMURA B. Levels of angiotensin and molecular biology of the tissue renin angiotensin systems. Regul Pept 1993; 43: 1-20. https://doi. org/10.1016/0167-0115(93)90403-u

[21] DINIZ GP, CARNEIRO-RAMOS MS, BARRETO-CHAVES ML. Angiotensin type 1 (AT1) and type 2 (AT2) receptors mediate the increase in TGF-betal in thyroid hormone-induced cardiac hypertrophy. Pflugers Arch 2007; 454: 75-81. https://doi.org/10.1007/s00424-006-0192-0

[22] KOBORI H, ICHIHARA A, SUZUKI H, TAKENAKA T, MIYASHITA Y et al. Role of the renin-angiotensin system in cardiac hypertrophy induced in rats by hyperthyroidism. Am J Physiol 1997; 273: H593-599. https://doi.org/10.1152/ ajpheart.1997.273.2.H593

[23] KLEIN I, OJAMAA K. Thyroid hormone and the cardiovascular system. N Engl J Med 2001; 344: 501-509. https://doi. org/10.1056/NEJM200102153440707

[24] MONTIEL M, RUIZ M, JIMENEZ E, MORELL M. Angiotensin converting enzyme in hyper- and hypothyroid rats. Horm Metab Res 1987; 19: 90-92. https://doi. org/10.1055/s-2007-1011749

[25] DINIZ GP, SENGER N, CARNEIRO-RAMOS MS, SANTOS RA, BARRETO-CHAVES ML. Cardiac ACE2/angiotensin 1-7/Mas receptor axis is activated in thyroid hormoneinduced cardiac hypertrophy. Ther Adv Cardiovasc Dis 2016; 10: 192-202. https://doi.org/10.1177/1753944715623228

[26] LIM VS. Thyroid function in patients with chronic renal failure. Am J Kidney Dis 2001 38: S80-84. https://doi. org/10.1053/ajkd.2001.27410

[27] LO JC, CHERTOW GM, GO AS, HSU CY. Increased prevalence of subclinical and clinical hypothyroidism in persons with chronic kidney disease. Kidney Int 2005; 67: 10471052. https://doi.org/10.1111/j.1523-1755.2005.00169.x

[28] ULRICH C, HEINE GH, GARCIA P, REICHART B, GEORG $\mathrm{T}$ et al. Increased expression of monocytic angiotensin-converting enzyme in dialysis patients with cardiovascular disease. Nephrol Dial Transplant 2006; 21: 15961602. https://doi.org/10.1093/ndt/gfl008

[29] TROJANOWICZ B, ULRICH C, KOHLER F, BODE V, SEIBERT E et al. Monocytic angiotensin-converting enzyme 2 relates to atherosclerosis in patients with chronic kidney disease. Nephrol Dial Transplant 2017; 32: 287-298. https:// doi.org/10.1093/ndt/gfw206

[30] ZOCCALI C, MALLAMACI F, TRIPEPI G, CUTRUPI S, PIZZINI P. Low triiodothyronine and survival in end-stage renal disease. Kidney Int 2006; 70: 523-528. https://doi. org/10.1038/sj.ki.5001566 
[31] ENIA G, PANUCCIO V, CUTRUPI S, PIZZINI P, TRIPEPI G et al. Subclinical hypothyroidism is linked to microinflammation and predicts death in continuous ambulatory peritoneal dialysis. Nephrol Dial Transplant 2007; 22: 538544. https://doi.org/10.1093/ndt/gfl605

[32] ZOCCALI C, TRIPEPI G, CUTRUPI S, PIZZINI P, MALLAMACI F. Low triiodothyronine: a new facet of inflammation in end-stage renal disease. J Am Soc Nephrol 2005; 16: 2789-2795. https://doi.org/10.1681/ASN.2005040356

[33] RYDER M, GHOSSEIN RA, RICARTE-FILHO JCM, KNAUF JA, FAGIN JA. Increased density of tumor-associated macrophages is associated with decreased survival in advanced thyroid cancer. Endocr Relat Cancer 2008; 15: 1069-1074. https://doi.org/10.1677/ERC-08-0036

[34] CUNHA LL, MORARI EC, GUIHEN AC, RAZOLLI D, GERHARD R et al. Infiltration of a mixture of immune cells may be related to good prognosis in patients with differentiated thyroid carcinoma. Clin Endocrinol (Oxf) 2012; 77: 918-925. oi: 10.1111/j.1365-2265.2012.04482.x

[35] Fiumara A, Belfiore A, Russo G, Salomone E, Santonocito GM et al. In situ evidence of neoplastic cell phagocytosis by macrophages in papillary thyroid cancer. J Clin Endocrinol Metab. 1997; 82: 1615-1620.

[36] EGAMI K, MUROHARA T, SHIMADA T, SASAKI K, SHINTANI S et al. Role of host angiotensin II type 1 receptor in tumor angiogenesis and growth. J Clin Invest 2003; 112: 67-75. https://doi.org/10.1172/JCI16645

[37] LINDBERG H, NIELSEN D, JENSEN BV, ERIKSEN J, SKOVSGAARD T. Angiotensin converting enzyme inhibitors for cancer treatment? Acta Oncol 2004; 43: 142-152. https://doi.org/10.1080/02841860310022346

[38] SONG T, CHOI CH, KIM MK, KIM ML, YUN BS et al. The effect of angiotensin system inhibitors (angiotensinconverting enzyme inhibitors or angiotensin receptor blockers) on cancer recurrence and survival: a meta-analysis. Eur J Cancer Prev 2017; 26: 78-85. https://doi.org/10.1097/ CEJ.0000000000000269

[39] MAO Y, XU X, WANG X, ZHENG X, XIE L. Is angiotensinconverting enzyme inhibitors/angiotensin receptor blockers therapy protective against prostate cancer? Oncotarget 2016; 7: 6765-6773. https://doi.org/10.18632/oncotarget.6837

[40] SHEN XZ, LI P, WEISS D, FUCHS S, XIAO HD et al. Mice with enhanced macrophage angiotensin-converting enzyme are resistant to melanoma. Am J Pathol 2007; 170: 21222134. https://doi.org/10.2353/ajpath.2007.061205

[41] HICKS BM, FILION KB, YIN H, SAKR L, UDELL JA et al. Angiotensin converting enzyme inhibitors and risk of lung cancer: population based cohort study. BMJ 2018; 363: k4209. https://doi.org/10.1136/bmj.k4209

[42] HAN CD, GE WS. Up-Regulation of Angiotensin-Converting Enzyme (ACE) Enhances Cell Proliferation and Predicts Poor Prognosis in Laryngeal Cancer. Med Sci Monit 2016; 22: 4132-4138. https://doi.org/10.12659/msm.896933
[43] ROMER FK. Angiotensin-converting enzyme and its association with outcome in lung cancer. Br J Cancer 1981; 43: 135-142. https://doi.org/10.1038/bjc.1981.21

[44] PROCHAZKA J, KREPELA E, SEDO A, VIKLICKÝ J, FIALA P. Aminopeptidases and angiotensin I-converting enzyme activities in primary human lung tumors and lung parenchyma. Neoplasma 1991; 38: 501-508.

[45] ROUlston JE, GAllOWAY PJ, DOUGLAS G. Plasma angiotensin-converting enzyme activity in patients with bronchial carcinoma. Br J Dis Chest 1986; 80: 229-234. https://doi.org/10.1016/0007-0971(86)90057-4

[46] NUSSINOVITCH N, PELEG E, YARON A, RATT P, ROSENTHAL T. Angiotensin converting enzyme in bleomycin-treated patients. Int J Clin Pharmacol Ther Toxicol 1988; 26: 310-313.

[47] AKSU S, BEYAZIT Y, HAZNEDAROGLU IC, CANPINAR H, KEKILLI $M$ et al. Over-expression of angiotensin-converting enzyme (CD 143) on leukemic blasts as a clue for the activated local bone marrow RAS in AML. Leuk Lymphoma 2006; 47: 891-896. https://doi. org/10.1080/10428190500399250

[48] ALBAYRAK M, CELEBI H, ALBAYRAK A, SAYILIR A, YESIL $Y$ et al. Elevated serum angiotensin converting enzyme levels as a reflection of bone marrow renin-angiotensin system activation in multiple myeloma. J Renin Angiotensin Aldosterone Syst 2012; 13: 259-264. https://doi. org/10.1177/147032031243707

[49] YU C, TANG W, WANG Y, SHEN Q, WANG B et al. Downregulation of ACE2/Ang-(1-7)/Mas axis promotes breast cancer metastasis by enhancing store-operated calcium entry. Cancer Lett 2016; 376: 268-277. https://doi. org/10.1016/j.canlet.2016.04.006

[50] SOTO-PANTOJA DR, MENON J, GALLAGHER PE, TALLANT EA. Angiotensin-(1-7) inhibits tumor angiogenesis in human lung cancer xenografts with a reduction in vascular endothelial growth factor. Mol Cancer Ther 2009; 8: 16761683. https://doi.org/10.1158/1535-7163.MCT-09-0161

[51] MENON J, SOTO-PANTOJA DR, CALLAHAN MF, CLINE JM, FERRARIO CM et al. Angiotensin-(1-7) inhibits growth of human lung adenocarcinoma xenografts in nude mice through a reduction in cyclooxygenase-2. Cancer Res 2007; 67: 2809-2815. https://doi.org/10.1158/0008-5472.CAN-063614

[52] KRISHNAN B, SMITH TL, DUBEY P, ZAPADKA ME, TORTI FM et al. Angiotensin-(1-7) attenuates metastatic prostate cancer and reduces osteoclastogenesis. Prostate 2013; 73: 71-82. https://doi.org/10.1002/pros.22542

[53] ZHOU L, ZHANG R, ZHANG L, YAO W, LI J et al. Angiotensin-converting enzyme 2 acts as a potential molecular target for pancreatic cancer therapy. Cancer Lett 2011; 307: 18-25. https://doi.org/10.1016/j.canlet.2011.03.011 


\section{Angiotensin converting enzymes ACE and ACE2 in thyroid cancer progression}

S. S. NARAYAN ${ }^{1}$, K. LORENZ ${ }^{1}$, J. UKKAT ${ }^{1}$, C. HOANG-VU' ${ }^{1}$, B. TROJANOWICZ ${ }^{2, *}$

\section{Supplementary information}

Supplementary Table S1. Thyroid tissues investigated in this study.

\begin{tabular}{lccccccc}
\hline No. & Tissue & Tumor & Age & Sex & CVD & CCB & ACEi/ARB \\
\hline 1 & FTC & T4N0M1 & 61 & F & - & - & - \\
2 & FTC & T4N1M0 & 86 & F & + & - & - \\
3 & FTC & T2N0M0 & 68 & F & + & + & \\
4 & FTC & T3N1M1 & 72 & M & - & - & - \\
5 & FTC & T3N0M0 & 13 & M & - & & \\
6 & FTC & T4N0M0 & 66 & M & - & - & + \\
7 & FTC & T4N0M0 & 36 & F & - & - & - \\
8 & FTC & T4N0M0 & 61 & M & - & - & - \\
9 & FTC & T4N1M1 & 65 & F & - & - & - \\
10 & FTC & T4N0M1 & 82 & F & - & - & - \\
11 & PTC & T2N0M0 & 17 & F & - & - & - \\
12 & PTC & T4N1M0 & 74 & F & + & - & + \\
13 & PTC & T4N0M0 & 57 & F & - & - & - \\
14 & PTC & T2N1M0 & 36 & M & - & - & - \\
15 & PTC & T1N1M0 & 25 & F & - & - & - \\
16 & PTC & T2N1M0 & 64 & F & - & - & + \\
17 & PTC & T1N1M0 & 11 & F & - & - & - \\
18 & PTC & T2N1M0 & 66 & M & - & - & - \\
19 & PTC & T4N1M1 & 15 & F & - & - & - \\
20 & PTC & T4N1M0 & 67 & M & + & + & - \\
21 & PTC & T3N1M1 & 77 & F & - & - & - \\
22 & PTC & T1N0M0 & 60 & F & - & - & - \\
23 & PTC & T4N1M0 & 12 & F & - & - & - \\
24 & PTC & T4N1M0 & 51 & F & - & - & - \\
25 & UTC & T4N0M1 & 76 & F & + & Fur. & - \\
26 & UTC & T3N0M0 & 52 & M & - & - & - \\
27 & UTC & T4N0M0 & 67 & M & + & + & - \\
28 & UTC & T3N1M1 & 63 & M & + & + & - \\
29 & UTC & T4N1M1 & 79 & F & + & + & - \\
30 & UTC & T3N0M1 & 28 & M & - & - & - \\
31 & UTC & T3N1M1 & 53 & M & - & - & - \\
32 & UTC & T4N1M0 & 71 & F & - & - & + \\
\hline & & & & & & & \\
\hline
\end{tabular}

\begin{tabular}{|c|c|c|c|c|c|c|c|}
\hline No. & Tissue & $\begin{array}{c}\text { Tumor } \\
\text { Stage }\end{array}$ & Age & Sex & CVD & СCB & ACEi/ARB \\
\hline 33 & UTC & T3N1M0 & 57 & $\mathrm{M}$ & + & + & - \\
\hline 34 & UTC & T4N1M1 & 62 & M & - & - & - \\
\hline 35 & UTC & T4N1M1 & 58 & $\mathrm{~F}$ & - & - & - \\
\hline 36 & Goiter & & 42 & $\mathrm{~F}$ & - & - & - \\
\hline 37 & Goiter & & 69 & M & - & - & - \\
\hline 38 & Goiter & & 69 & $\mathrm{~F}$ & - & - & - \\
\hline 39 & Goiter & & 71 & $\mathrm{~F}$ & + & + & - \\
\hline 40 & Goiter & & 53 & M & - & - & - \\
\hline 41 & Goiter & & 46 & $\mathrm{~F}$ & - & - & - \\
\hline 42 & Goiter & & 56 & $\mathrm{~F}$ & - & - & - \\
\hline 43 & Goiter & & 54 & F & - & - & - \\
\hline 44 & Goiter & & 36 & $\mathrm{~F}$ & - & - & - \\
\hline 45 & Goiter & & 55 & $\mathrm{~F}$ & - & - & - \\
\hline 46 & Goiter & & 59 & M & - & - & - \\
\hline 47 & Goiter & & 47 & M & - & - & - \\
\hline 48 & Goiter & & 56 & $\mathrm{~F}$ & - & - & - \\
\hline 49 & Goiter & & 41 & $\mathrm{~F}$ & - & - & - \\
\hline 50 & Adenoma & & 59 & $\mathrm{~F}$ & - & - & + \\
\hline 51 & Adenoma & & 42 & $\mathrm{~F}$ & - & - & - \\
\hline 52 & Adenoma & & 69 & $\mathrm{~F}$ & - & - & - \\
\hline 53 & Adenoma & & 45 & M & - & - & - \\
\hline 54 & Adenoma & & 38 & $\mathrm{~F}$ & - & - & - \\
\hline 55 & Adenoma & & 52 & M & - & - & - \\
\hline 56 & Adenoma & & 43 & $\mathrm{~F}$ & + & + & - \\
\hline 57 & Adenoma & & 58 & M & + & + & - \\
\hline 58 & Adenoma & & 33 & M & - & - & - \\
\hline 59 & Adenoma & & 54 & M & - & - & + \\
\hline 60 & Adenoma & & 53 & $\mathrm{~F}$ & - & - & - \\
\hline 61 & Adenoma & & 68 & M & + & + & - \\
\hline
\end{tabular}

F, female, $\mathrm{M}$, male, CVD, cardiovascular disorder, CCB, calcium channel blockers, $\mathrm{ACEi} / \mathrm{ARB}$, angiotensin converting enzyme inhibitors / angiotensin II receptor blockers, Fur., furosemide, $+/-$, yes/no.

Supplementary Table S2. Primers for qPCR.

\begin{tabular}{llll}
\hline Gene & $\begin{array}{l}\text { Amplicon } \\
(\mathbf{b p})\end{array}$ & $\begin{array}{l}\text { Annealing } \\
\left({ }^{\circ} \mathbf{C}\right)\end{array}$ & Primer Sequence \\
\hline 18S S & 151 & 60 & GTA ACCCGTTGA ACCCCATT \\
18S AS & 151 & 60 & CCATCC AATCGGTAGTAGCG \\
ACE S & 111 & 60 & GTGTGGAACGAGTATGCCGA \\
ACE AS & 111 & 60 & CTTCAGGGTGTGGTTGGCTA \\
ACE2 S & 108 & 60 & CATTGGAGCAAGTGTTGGATCTT \\
ACE2 AS & 108 & 60 & GAGCTAATGCATGCCATTCTCA \\
\hline
\end{tabular}

